JURNAL SEHAT MASADA VOLUME XIII NOMOR 2 Juli $2019 \quad$ ISSN : 1979-2344

\title{
HUBUNGAN KEBIASAAN MEMINUM TEH DAN KOPI DENGAN KEJADIAN ANEMIA PADA IBU HAMIL DI BPM BIDAN "E" DESA CIWANGI KECAMATAN BALUBUR LIMBANGAN KABUPATEN GARUT
}

\author{
${ }^{1}$ Oktarina Sri Iriani, ${ }^{2}$ Ulfah \\ Program Studi Diploma Tiga Kebidanan STIKes Dharma Husada Bandung \\ oktarina@stikesdhb.ac.id
}

\begin{abstract}
ABSTRAK
Anemia adalah penurunan kapasitas darah dalam membawa oksigen karena jumlah sel darah merah yang kurang dari normal. Menurut World Health Organisation (WHO), 40\% kematian ibu di negara berkembang berkaitan dengan anemia pada kehamilan dan kebanyakan anemia ini disebabkan oleh defisiensi besi. Anemia defisiensi besi adalah anemia yang terjadi akibat kekurangan zat besi dalam darah. Zat besi yang berasal dari makanan seperti daging, hati, telur, sayuran hijau dan buah- buahan diabsorpsi di usus halus. Penyerapan zat besi ini dipengaruhi oleh faktor adanya protein hewani dan vitamin $\mathrm{C}$, sedangkan yang menghambat serapan adalah kopi, teh, garam kalsium dan magnesium karena bersifat mengikat zat besi, Di samping itu, dalam the dan kopi ada senyawa yang bernama tanin. Tanin ini dapat mengikat beberapa logam seperti zat besi, kalsium, dan aluminium, lalu membentuk ikatan kompleks secara kimiawi. Karena dalam posisi terikat terus, maka senyawa besi dan kalsium yang terdapat pada makanan sulit diserap tubuh sehingga menyebabkan penurunan zat besi $(\mathrm{Fe})$. Tujuan penelitian ini untuk mengetahui Hubungan Kebiasaan Meminum Teh dan Kopi Dengan kejadian Anemia pada Ibu Hamil di BPM Ny. E Periode April-Juni 2018 Kabupaten Garut. Jenis penelitian kuantitatif dengan pendekatan Cross sectional. Jumlah sampel sebanyak 50 orang yang di ambil secara insidental sampling. Data yang digunakan yaitu data primer yang diambil secara langsung menggunakan lembar ceklis dan alat cek $\mathrm{Hb}$ Easy Touch. Analisa data berupa univariat dan bivariat dengan menggunakan uji chi- square. Hasil data 28 orang $(56,0 \%)$ mengalami anemia dan 22 orang $(44,0 \%)$ tidak anemia. Terdapat korelasi antara kebiasaan meminum teh dan kopi dan kasus anemia pada ibu hamil di BPM Ny. E chi square $(24.219)>$ chi tabel $(7,38)$ dan p value $(0,000)<\alpha$ $(0,05)$. Penelitian ini menyarankan bagi ibu hamil agar menghindari meminum teh atau kopi secara langsung sebelum dan sesudah makan karena dapat menghambat penyerapan zat besi dalam darah.
\end{abstract}

Kata Kunci : Konsumsi Teh dan Kopi, Anemia

\begin{abstract}
Anemia is a decrease in blood capacity in carrying oxygen because the number of red blood cells is less than normal. According to the World Health Organization (WHO), 40\% of maternal deaths in developing countries are associated with anemia in pregnancy and most of these anemia are caused by iron deficiency. Iron deficiency anemia is anemia caused by iron deficiency in the blood. Iron derived from foods such as meat, liver, eggs, green vegetables and fruits are absorbed in the small intestine. The absorption of iron is influenced by the presence of animal protein and vitamin $C$, while the inhibition of absorption is coffee, tea, calcium and magnesium salts because it is binding to iron, In addition, in tea and coffee there is a compound called tannin. This tannin can bind several metals such as iron, calcium, and aluminum, and form a complex chemical bond. Because in a bonded position continues, the iron and calcium compounds found in food is difficult to absorb the body causing decrease in iron $(\mathrm{Fe})$. The purpose of this study to determine the correlation between drinking tea and coffee habits with the incidence of anemia in pregnant mother at BPM Ny. E Period AprilJune 2018 Garut regency. Quantitative research type with Cross sectional approach. The number of samples as many as 50 people are taken incidental sampling. The data used are primary data taken
\end{abstract} Jurnal Penelitian Kesehatan STIKes Dharma Husada Bandung 
directly using checklists and check tools Hb Easy Touch. Data analysis was univariate and bivariate using chi-square test. Results of data 28 people (56.0\%) had anemia and 22 people (44.0\%) were not anemic. There is a correlation between drinking tea and coffee habits and cases of anemia in pregnant women in BPM Ny. E chi square (24.219)> chi table $(7,38)$ and $p$ value $(0,000)<\alpha(0,05)$. This study suggests for pregnant women to avoid drinking tea or coffee directly before and after meals because it can inhibit the absorption of iron in the blood.

Keywords : Tea and Coffe Consumtion, Amenia

\section{PENDAHULUAN}

Prevalensi anemia pada ibu hamil di Indonesia menurut Riset Kesehatan Dasar (Riskesdas) tahun 2013 sekitar 37,1\%, sedangkan Angka prevalensi anemia ibu hamil di Jawa Barat adalah sebesar 13,5\%. Dinkes kabupaten setempat mencatat, sekitar 40 persen ibu hamil diketahui menderita anemia. Kabid Kesehatan Keluarga Dinkes mengatakan kasus kematian ibu melahirkan di Garut sepanjang 2014 mencapai 45 kasus. Angka tersebut meningkat dibandingkan 2013 (37 kasus). ${ }^{2}$ Menurut buku laporan bulanan KIA di puskesmas limbangan dalam tahun 2017 terdapat 1484 ibu hamil memeriksakan kehamilan dan di dapatkan 40,6\% ibu hamil tidak anemia dan 59,4\% ibu hamil dengan anemia dimana 91,9\% ibu hamil dengan anemia ringan dan $8,9 \%$ ibu hamil dengan anemia berat.

Anemia defisiensi besi lebih cenderung berlangsung di negara berkembang dan umumnya disebabkan oleh kekurangan nutrisi, infeksi dan infestasi, perdarahan dan hemoglobinopati. ${ }^{2,3}$ Selama kehamilan akan terjadi peningkatan volume plasma sehingga mengakibatkan hemodilusi yang terjadi pada trimester II, pada $6 \%$ ibu hamil bisa mencapai di bawah $11 \mathrm{~g} / \mathrm{dl}$. Pada kehamilan lanjut hal ini merupakan kondisi abnormal dan biasanya berhubungan dengan defisiensi besi. Jumlah $\mathrm{Fe}$ yang diabsorbsi dari makanan dan cadangan dalam tubuh biasanya tidak mencukupi kebutuhan ibu selama kehamilan sehingga diperlukan penambahan asupan zat besi untuk membantu mengembalikan kadar hemoglobin. ${ }^{4} \quad$ Kondisi anemia dapat meningkatkan risiko kematian ibu pada saat melahirkan, melahirkan bayi dengan berat badan lahir rendah, janin dan ibu mudah terkena infeksi, keguguran, dan meningkatkan risiko bayi lahir prematur. ${ }^{7}$ Faktor yang dapat mempengaruhi perubahan kadar Hemoglobin yakni dari konsumsi makan sehari-hari. Tablet besi sebaiknya diminum dengan menggunakan air jeruk atau air putih karena membantu proses penyerapan zat besi. Dan hindari mengkonsumi tablet zat besi dengan menggunakan air teh, kopi, dan susu karena akan menghambat proses penyerapan zat besi, selain itu tanin yang merupakan polifenol dan terdapat di dalam kopi dan teh. Senyawa ini akan mengikat besi sehingga menurunkan zat besi yang diserap oleh tubuh. Apabila zat besi tidak dapat terserap oleh tubuh, maka besi yang berada dalam duodenum akan terbuang bersama dengan feses. Hal ini menyebabkan cadangan besi dalam tubuh juga berkurang, 
JURNAL SEHAT MASADA VOLUME XIII NOMOR 2 Juli $2019 \quad$ ISSN : 1979-2344

berkurangnya jumlah cadangan besi dalam tubuh dapat menyebabkan terjadinya anemia pada ibu hamil. ${ }^{7}$

Tanin yang merupakan polifenol yang terdapat dari teh dan kopi dapat menyebabkan tidak efektifnya cara kerja tablet fe yang dimana tugas nya untuk menambah darah dan menaikan kadar hemoglobin beralih menjadi zat yang tidak berguna bagi tubuh dan dibuang begitu saja melalui feses, maka dengan demikian karena menurun nya cara kerja tablet fe maka kurang juga asupan zat besi pada ibu hamil sehingga dapat menyebabkan turun nya kadar hemogobin pada ibu hamil. Tanin yang terdapat dalam teh dapat menurunkan absorbsi zat besi sampai dengan $80 \%$. Minum teh satu jam sesudah makan dapat menurunkan absorbsi hingga $85 \%{ }^{8}$ Berdasarkan studi pendahuluan di BPM Ny. E di temukan masalah pada ibu hamil dimana 2 orang ibu hamil mengalami penurunan kadar hemoglobin yaitu pada salah satu ibu hamil dari kadar Hemoglobin 9,8 gram \% menjadi 9,6 gram \% dan dari 10,2 gram \% menjadi 10 gram \% dan setelah dilakukan wawancara keduanya mengatakan hampir setiap hari mengkonsumsi teh dan kopi.

\section{METODOLOGI PENELITIAN}

Dalam penelitian ini penulis menggunakan penelitian secara kuantitatif dengan desain korelasi. Yaitu penelitian yang diarahkan untuk menjelaskan hubungan antara dua variabel yaitu variabel bebas dengan variabel terikat. ${ }^{18}$ Penelitian ini bertujuan untuk mengetahui hubungan kebiasaan meminum teh dan kopi dengan kejadian anemia pada ibu hamil. Pendekatan waktu dalam penelitian ini menggunakan penelitian cross sectional (poin time approach) artinya, tiap subyek penelitian hanya diobservasi sekali saja dan pengukuran dilakukan terhadap status karakter atau variabel subyek pada saat penelitian. Populasi pada penelitian ini adalah seluruh ibu hamil trimester II dan Trimester III yang melakukan pemeriksaan ANC dan $\mathrm{Hb}$ di BPM Ny.Waktu penelitian April - Juni 2018. Sampel dari penelitian ini diambil sesuai dengan kriteria. Ibu hamil yang melakukan pemeriksaan ANC trimester II dan trimester III dan Hb di BPM dan wilayah kerja Ny. E yang sering mengkonsumsi teh dan kopi sebanyak $50 \mathrm{ibu}$ hamil. Instrumen yang digunakan dalam penelitian ini menggunakan lembar ceklis dalam menentukan kebiasaan ibu hamil meminum teh dan kopi, dan alat cek hemoglobin dengan merk Easy Touch. Analisa data yang dilakukan dalam penelitian ini yaitu Analisa univariat digunakan untuk melakukan analisis terhadap satu variabel penelitian. Setiap variabel ditampilkan dalam bentuk distribusi frekuensi dan grafik, selanjutnya dianalisis terhadap tampilan dan dalam bentuk presentase (\%). Analisa bivariat untuk mengukur hubungan kebiasaan meminum teh dan kopi dengan kekjadian anemia maka dilakukan uji statistik dengan metode Chi Square $\left(\mathrm{x}^{2}\right)$. 


\section{HASIL DAN PEMBAHASAN}

1. Analisis Univariat

a. Distribusi Frekuensi Kebiasaan Meminum Teh dan Kopi Pada Ibu Hamil di BPM Ny. E

Tabel 1 Distribusi Frekuensi Kebiasaan Meminum Teh dan Kopi Pada Ibu Hamil di BPM Ny. E

\begin{tabular}{rccc}
\hline No & Kebiasaan Meminum & f & \% \\
\hline 1 & Teh & 23 & 46.0 \\
2 & Kopi & 8 & 16.0 \\
3 & Teh \& Kopi & 19 & 38.0 \\
\hline \multicolumn{2}{c}{ Total } & $\mathbf{5 0}$ & $\mathbf{1 0 0 . 0}$ \\
\hline
\end{tabular}

Berdasarkan tabel diatas, dapat dilihat bahwa dari 50 responden yang diteliti ternyata 23 orang $(46,0 \%)$ memiliki kebiasaan meminum teh, 8 orang $(16,0 \%)$ memiliki kebiasaan meminum kopi dan 19 orang $(38,0 \%)$ memiliki kebiasaan meminum teh \& kopi.
Hal ini mengindikasikan bahwa sebagian ibu hamil di BPM Ny. E memiliki kebiasaan meminum teh.

b. Distribusi Frekuensi Kejadian Anemia Pada Ibu Hamil di BPM Ny. E

Tabel 2 Distribusi Frekuensi Kejadian Anemia Pada Ibu Hamil di BPM Ny. E

\begin{tabular}{clcc}
\hline No & Kejadian Anemia & f & $\%$ \\
\hline 1 & Anemia & 28 & 56 \\
2 & Tidak anemia & 22 & 44 \\
\hline & Total & $\mathbf{5 0}$ & $\mathbf{1 0 0}$ \\
\hline
\end{tabular}

Berdasarkan tabel diatas, dapat dilihat bahwa dari 50 responden yang diteliti ternyata 28 orang $(56,0 \%)$ mengalami anemia dan 22 orang $(44,0 \%)$ tidak anemia. Hal ini mengindikasikan bahwa sebagian besar iu hamil di BPM Ny. E mengalami anemia

\section{Analisis Bivariat}

\section{a. Hubungan Kebiasaan Meminum Teh Dan Kopi Dengan Kejadian Anemia Pada Ibu Hamil di BPM Ny. E}

Tabel 3 Hubungan Antara Kebiasaan Meminum Teh Dan Kopi Dengan Kejadian Anemia Pada Ibu Hamil di BPM Ny.E

\begin{tabular}{|c|c|c|c|c|c|c|c|}
\hline \multirow{3}{*}{$\begin{array}{l}\text { Kebiasaan } \\
\text { Minum }\end{array}$} & \multicolumn{6}{|c|}{ Kejadian Anemia } & \multirow[t]{3}{*}{ P-Value } \\
\hline & \multicolumn{2}{|c|}{ Anemia } & \multicolumn{2}{|c|}{ Tidak Anemis } & & & \\
\hline & $\mathrm{f}$ & $\%$ & $\mathrm{f}$ & $\%$ & $\mathrm{f}$ & $\%$ & \\
\hline Teh & 21 & 42,0 & 2 & 4,0 & 23 & 46,0 & \multirow{4}{*}{0,000} \\
\hline Kopi & 4 & 8,0 & 4 & 8,0 & 8 & 16,0 & \\
\hline Teh \& Kopi & 3 & 6,0 & 16 & 32,0 & 19 & 38,0 & \\
\hline Total & 28 & 56,0 & 22 & 44,0 & 50 & 100,0 & \\
\hline
\end{tabular}

Hasil tabulasi silang antara kebiasaan mengalami anemia dan 2 orang $(4,0 \%)$ tidak meminum teh dan kopi dengan kejadian anemia pada ibu hamil, dari 23 orang yang mengalami anemia. Dari 8 orang yang memiliki kebiaasan meminum teh ternyata memiliki kebiasaan meminum kopi ternyata terdapat sebanyak 21 orang $(42,0 \%)$ yang masing-masing terdapat sebanyak 4 orang 
mengalami anemia. Dari 19 orang yang memiliki kebiasaan meminum teh \& kopi ternyata terdapat 3 orang $(26,0 \%)$ mengalami anemia dan 16 orang $(32,0 \%)$ tidak mengalami anemia. Hal ini mengindikasikan bahwa sebagian ibu hamil di BPM Ny. E memiliki kebiasaan meminum teh dan mengalami anemia.

Berdasarkan hasil perhitungan statistik tersebut diperoleh nilai chi square sebesar 24.219. Hasil uji statistik menunjukkan bahwa chi square $(24.219)>$ chi tabel $(7,38)$ dan $\mathrm{p}$ value $(0,000)<\alpha(0,05)$, maka itu Ho ditolak. Artinya, terdapat hubungan antara kebiasaan meminum teh dan kopi dengan kejadian anemia pada ibu hamil.

Penyerapan zat besi sangat dipengaruhi oleh kombinasi makanan yang diserap pada waktu makan makanan tertentu, terutama teh kental yang akan menimbulkan pengaruh penghambatan yang nyata pada penyerapan zat besi. ${ }^{8}$ Senyawa tanin dari teh dan kopi yang berlebihan dalam darah akan mengganggu penyerapan zat besi. Tubuh kekurangan zat besi maka pembentukan butir darah merah (hemoglobin) berkurang sehingga mengakibatkan anemia.Pengaruh penghambatan tanin dapat dihindarkan dengan cara tidak minum teh dan kopi setelah selesai makan agar tidak mengganggu penyerapan zat besi. Tanin yang terdapat dalam teh dan kopi dapat menurunkan absorbsi zat besi sampai dengan $80 \%$. Minum teh atau kopi satu jam sesudah makan dapat menurunkan absorbsi hingga $85 \%{ }^{8}$
Berdasarkan hasil penelitian ini menunjukan bahwa dari 50 responden yang diteliti ternyata 28 orang $(56,0 \%)$ mengalami anemia dan 22 orang $(44,0 \%)$ tidak anemia. Hal ini mengindikasikan bahwa sebagian besar ibu hamil di BPM Ny. E mengalami anemia.

Anemia dalam kehamilan adalah kadar hemoglobin kurang dari $11 \%$ dl\%. Anemia pada trimester kedua saat kadar hemoglobinnya kurang dari 10,5 g/dl dan anemia pada trimester satu dan tiga saat kadar hemoglobinnya kurang dari $11 \mathrm{~g} / \mathrm{dl} .{ }^{9}$ Pengaruh anemia dalam kehamilan dapat menyebabkan abortus, hambatan tumbuh kembang, mudah terjadi infeksi, ancaman dekompensasi kordis, ketuban pecah dini, persalinan antepartum. Selain itu membahayakan pada masa kehamilan, anemia juga berbahaya pada saat persalinan dan kala nifas, sehingga sangat penting pemenuhan zat besi pada ibu hamil untuk menghindari anemia.

Faktor penyebab anemia menurut (Suprapto dkk, 2014) penyebab umum dari anemia antara lain : kekurangan zat besi, pendarahan usus, pendarahan, genetik, kekurangan vitamin B12, kekurangan asam folat, gangguan sumsum tulang, dan penyerapan.

Penyebab anemia defisiensi besi selain asupan makanan sumber zat besi kurang dari kebutuhan, juga akibat bahan makanan sumber zat besi yang dikonsumsi tingkat absorpsinya rendah atau sering mengkonsumsi bahan makanan yang mengandung zat penghambat / inhibitor 
penyerapan zat besi.

Pencegahan anemia kekurangan zat besi diberikan dengan memberikan tablet Fe. Terlebih lagi ibu hamil sangat rentan terkena anemia. Dengan melakukan pemeriksaan kehamilan maka dapat diketahui ibu berisiko menglami anemia dan juga pencegahan yang dapat dilakukan apalagi bila ibu hamil mendekati usia persalinan. Kekurangan darah akan membahayakan nyawa ibu hamil. Pemberian tablet $\mathrm{Fe}$ yaitu 90 tablet selama kehamilan dimimun setiap hari satu tablet pada pagi atau malam hari dengan menggunakan air putih atau boleh menggunalan air putih dengan perasan jeruk.

Tanin merupakan polifenol yang terdapat di dalam teh, kopi dan beberapa jenis sayuran serta buah, juga dapat menghambat absorbsi besi dengan cara mengikat besi. Bila besi tubuh tidak telalu tinggi, sebaiknya tidak minum teh atau kopi pada waktu makan. ${ }^{8}$ Teh dan kopi mengandung tanin yang merupakan polifenol yang dapat menghambat absorbsi besi dengan cara mengikatnya. Rosander, dkk melaporkan bahwa penyerapan zat besi sangat dipengaruhi oleh kombinasi makanan yang disantap pada waktu makan. Sejenis makanan khas Amerika Latin terbuat dari tepung maezena, beras dan kacang hitam mengandung besi sebanyak $0,17 \mathrm{mg}$. Bila ditambah dengan vitamin $\mathrm{C}$ dalam bentuk asam askorbat murni $50 \mathrm{mg}$ atau kembang kol (125 mg), jumlah besi yang terserap akan meningkat berturut- turut menjadi $0,41 \mathrm{mg}$ atau $0,58 \mathrm{mg}$. Sebaliknya apabila minum teh dan kopi, terutama teh kental maka hal ini akan menimbulkan pengaruh penghambatan nyata pada penyerapan besi (De Mayer, 1993 dalam Harnany, 2006). ${ }^{8}$

Terdapat Banyak solusi dalam makanan yang dapat membantu meningkatkan kadar hemoglobin dalam darah, terdapat dua bentuk zat besi yang dapat diserap tubuh dari makanan yang dikonsumsi yaitu : zat besi heme yang umumnya terdapat di dalam bahan makanan hewani seperti daging unggas, daging merah dan ikan. Begitupula zat besi non-heme yang terdapat dalam bahan makanan nabati seperti kentang, sayuran berdaun hijau seperti bayam, biji-bijian, kacang- kacangan seperti kacang merah, dan buah-buahan kering seperti kismis. ${ }^{19}$

\section{SIMPULAN}

1. Distribusi frekuensi ibu hamil dari 50 responden yang diteliti ternyata 23 orang $(46,0 \%)$ memiliki kebiasaan meminum teh, 8 orang $(16,0 \%)$ memiliki kebiasaan meminum kopi dan 19 orang $(38,0 \%)$ memiliki kebiasaan meminum teh \& kopi.

2. Distribusi ibu hamil periode April Juni 2018 bahwa dari50 responden yang diteliti ternyata 28 orang $(56,0 \%)$ mengalami anemia dan 22 orang (44\%) tidak anemia.

3. Ada hubngan kebiasaan minum teh dan kopi dengan kejadian anemia pada ibu hamil trimester II dan III di wilayah kerja BPM Ny. E Desa Ciwangi Kecamatan Balubur Limbangan Kabupaten Garut 
periode April- Juni tahun 2018 diperoleh nilai Chi Square sebesar 24.219. Hasil uji statistik menunjukan bahwa Chi Square $(24.219)>$ Chi Tabel $(7,38)$ dan $p$ value $(0,000)>\alpha(0,05)$.

\section{SARAN}

1. Disarankan bagi ibu hamil agar menghindari meminum teh atau kopi secara langsung sebelum dan sesudah makan, dan setelah atau sebelum meminum tablet penambah darah karena dapat menghambat penyerapan zat besi dalam darah.

2. Bagi tenaga kesehatan diharapkan dapat memprioritaskan kegiatan upaya promotif seperti pendidikan kesehatan melalui penyuluhan, konseling, secara berkesinambungan kepada ibu hamil yang memeriksakan kehamilannya tentang cara meminum tablet Fe yang benar.

\section{DAFTAR PUSTAKA}

1. Fadina, Indrawati Nur, Ali Hirowati. Hubungan Suplementasi Tablet Fe dengan Kadar Hemoglobin pada Ibu Hamil Trimester III di Puskesmas Air Dingin Kota Padang. Jurnal kesehatan andalas.2017.

2. Riskesdas. Laporan hasil Riset Kesehatan Dasar (Riskesdas) tahun 2013. Jakarta: Badan Penelitian dan Pengembangan Kesehatan Kementerian Kesehatan RI; 2013.

3. Dinas Kesehatan Provinsi Jawa Barat Tahun 2010.

4. Prawirohardjo S. Ilmu Kebidanan. Edisi ke-4. Jakarta: PT Bina Pustaka Sarwono Prawirohardjo; 2010.

5. Survei Demografi dan Kesehatan Indonesia Tahun 2012 (SDKI 2012). Diunduh dari: https://www.bps.go.id
6. WHO, 2015 http://www.who.int/mediacentre/factsheet s/fs348/en

7. Kemenkes RI. Jurnal Kesehatan Reproduksi. Vol. 7. No 2. Halaman 72. Jakarta, Agustus 2016. ISSN : 2087703X. e-ISSN : 2354-8762.

8. Septiawan, Hubungan Kebiasaan Minum Teh dengan Kejadian Anemia pada Ibu Hamil Trimester II. Lampung, Vol. VI, No. 2, Oktober 2015.

9. Cuningham, Leveno, Bloom, Rouse, Spong. Obstetri Williams Volume 2 Edisi 23. Jakarta: EGC; 2013;1138-1140.

10. Broek van den NR, Letsky EA. Etiology of anemia in pregnancy in south Malawi.Am. J. Clin. Nutr. 2000; 72(1):247S-256S.

11. American College of Obstetricians and Gynecologists : Anemia in pragnancy. Committe Opinion No. 95. July 2008. 451.

12. Tarwoto, Wasnida. Anemia pada Ibu Hamil Konsep dan Penatalaksanaan. Jakarta: Trans Info Media. 2013.

13. Baliga, Ragavendra. Crash Course Internal Medicine: Elsevier Mosby; 2007.

14. Sharma JB, Shankar M. Anemia in Pregnancy. JIMSA. 2010;23;253-9.

15. Sukrat B. and Sirichotiyakul S. The prevalence and causes of anemia during pregnancy in Maharaj Nakorn Chiang Mai Hospital. J. Med. Assoc. Thai 2006; 89(Suppl 4):S142-146.

16. Susiloningtyas, Is. Pemberian Zat Besi (Fe) Dalam Kehamilan.74-136-1-SM.

17. Arikunto, Suharsimi. 2013. Prosedur Penelitian Suatu Pendekatan Praktik. Jakarta: Salemba Medika.

18. Notoatmojo, S. 2013. Metode Penelitian Kesehatan. Jakarta : Rineka Cipta 
